\title{
Csizner Zoltán
}

\section{A szervezett bünözés hatása a rendvédelmi szervek fejlődésére}

\section{The effect of the organized crime on the development of the law enforcement organizations}

Mottó:

„Amikor a rossz emberek összeállnak, a jóknak társulniuk kell, különben egyenként elbuknak, cseppet sem sajnált áldozatként

egy hitvány küzdelemben."

Edmund Burke ${ }^{1}$

\begin{abstract}
Absztrakt
Sok tanulmány és dolgozat született már arról, hogy honnan indult, mit jelent, illetve miként és mivé fejlődött a szervezett bünözés. Mint ahogy azzal is sokan foglalkoztak már, hogy az egyes rendvédelmi szervek hogyan fejlődtek, milyen jellemző stádiumok jelentek meg müködésük során. Arról azonban már kevesebbet lehet olvasni, hogy ez a két dolog milyen kölcsönhatásban áll vagy állt egymással, pontosabban a szervezett bünözés, valamint annak a fejlődése milyen hatásokat gyakorolt a rendvédelmi szervekre, milyen szervezeti változásokat generált egy-egy kiemelt büncselekmény vagy egy-egy új elkövetési módszer. Jelen dolgozatban a szervezett bünözés fogalmának és jellemzőinek meghatározását követően ezúttal az kerül bemutatásra, hogy a fejlődését és változásait milyen események, körülmények határozták meg Magyarországon, illetve milyen ideiglenes vagy állandósult szervezetek vették fel a harcot ezekkel a jelenségekkel. Végül pedig a szervezeti hatások mellett azok a képzési lehetőségek kerülnek ismertetésre, amelyek a rendvédelem müködésének hatékonyságát segítették elö.
\end{abstract}

Kulcsszavak: szervezett bünözés, rendvédelem, fejlődés, képzés

1 Edmund Burke (1729-1797) ír származású angol író, politikus, filozófus. 


\begin{abstract}
Many studies and dissertations have been written on the questions where organized crime was started, what it means, and how and into what it has evolved. Just as much has been already dealt with the question how the law enforcement agencies have evolved, what typical stages have appeared during their operation. However, it is less clear how these two things interact or were interrelated, and more specifically, how organized crime and its development on has impacted law enforcement agencies, what organizational changes have been generated by a particular crime or a new offense method. In this dissertation, after defining the concept and characteristics of the organized crime, this time I would like to present the events and circumstances that determined its development and changes in Hungary, as well as what temporary or permanent organizations were fighting against these phenomena. Finally, besides the organizational effects, I present the training opportunities that contributed to the effectiveness of law enforcement.
\end{abstract}

Keywords: organized crime, law enforcement, development, training

\title{
A szervezett bűnözés meghatározása, főbb jellemzői
}

A szervezett bünözés meghatározásának több megközelítése is lehetséges, akár a nemzetközi, akár a hazai értelmezések között válogatunk. Az Egyesült Nemzetek Szervezete (ENSZ) 1975-ben Torontóban foglalkozott a szervezett bünözés kérdésével, amely során a következő megállapítást tette:

„Szervezett bünözés alatt olyan nagyarányú és összetett bünözői tevékenység értendö, amelyet csoportok folytatnak - legyenek akármennyire lazán vagy szorosan szervezettek - a csoportban résztvevők meggazdagodása érdekében és az egész közösség, illetve a közösség tagjainak a kárára. Ezt gyakran a jog megszegése (beleértve a személyek elleni jogsértéseket) révén, és gyakran politikai korrupcióval kísérve hajtják végre." (URL1)

2000 decemberében, Palermóban az ENSZ ismét napirendre tüzte a szervezett bünözés kérdését, és az ülés végén elfogadásra került a Nemzetközi Szervezett Bünözés Elleni Egyezmény (továbbiakban: Egyezmény), amelyet Magyarország a 2006. évi CI. törvénnyel ratifikált. A Palermói Egyezményként ismertté vált szerződés szerint a szervezett bünözői csoport ,,bizonyos ideig fennálló, három vagy több föböl álló strukturált csoport, amely összehangoltan müködik egy vagy több, a jelen Egyezményben meghatározott súlyos büncselekmény 
elkövetése céljából, közvetlen vagy közvetett módon pénzügyi vagy más anyagi haszon megszerzésére törekedve". ${ }^{2}$

Az Interpol meghatározása szerint a szervezett bünözői csoport „... bármely egységes szervezetü csoport, amelynek legföbb célja az, hogy illegális tevékenységek révén pénzt szerezzen, és gyakran a félelem és korrupció segitségével biztositja túlélését." (Szendrei, 2010,161.)

Az Európai Unió (EU) Tanácsának 2008/841/IB. 2008. november 24-én elfogadott kerethatározata szerint a bünszervezet „Olyan, kettőnél több személyböl álló, hosszabb idöre létrejött szervezett csoport, amely összehangoltan müködik, és amelynek célja az, hogy legalább négy évig terjedö szabadságvesztéssel vagy szabadságelvonással járó intézkedéssel vagy annál szigorúbb szankcióval büntetendö büncselekményeket kövessen el közvetlen vagy közvetett pénzügyi, vagy egyéb anyagi haszonszerzés érdekében”. (URL2) A fentiek mellett a hazai jogalkalmazásban - és így a rendvédelemben is - mégis a leggyakrabban alkalmazott definíció a Büntető Törvénykönyv (Btk.) által megfogalmazott értelmezés, mely szerint a bünszervezet a ,... három vagy több személyböl álló, hosszabb idöre hierarchikusan szervezett, konspirativan müködö csoport, melynek célja ötévi vagy ezt meghaladó szabadságvesztéssel büntetendö szándékos büncselekmény elkövetése." ${ }^{3}$

A megfogalmazások eltérősége mellett megtalálhatók azok a közös pontok, amelyek minden esetben jellemzők a bünszervezetre, a szervezett bünelkövetésre:

- kettő vagy több személyböl álló csoport;

- hosszú távú, előre be nem határolt időtartamú müködés;

- súlyos büncselekmények elkövetésére jött létre.

Az ismertetett meghatározások között az egyik alapvető különbség az, hogy míg a nemzetközi fogalmi rendszer a közös ismérveken túl az anyagi haszonszerzést tartja fontosnak, addig a hazai szabályozás a legutóbbi módosítás ${ }^{4}$ után a hierarchikus felépítést és a konspirált müködést követeli meg szükséges feltételként. A hierarchikus felépítés tényállási elemként történő megjelenítésének némileg ellentmondani látszik mind az EU Tanácsának kerethatározata ${ }^{5}$, amely szerint a kidolgozott szervezeti felépítés nem feltétele a szervezett csoport

2 Az Egyesült Nemzetek keretében, Palermóban, 2000. december 14-én létrejött, a nemzetközi szervezett bünözés elleni Egyezmény kihirdetéséről szóló 2006. évi CI. törvény 2. cikk a) pontja.

3 A Büntető Törvénykönyvről szóló 2012. évi C. tv. 459. § (1) bek. 1. pont.

4 2019. évi LXVI. törvény 107. §. Hatályos: 2019. július 10-től.

5 A Tanács 2008/841/IB kerethatározata, 1. cikk 2. bekezdés. 
megállapításának, mind pedig a SOCTA ${ }^{6}$ értékelés, amelyben a laza kötődésủ vagy a sejtszerüen müködő szervezett bünözői csoportok sem ismeretlenek. Bár a bünszervezetek közvetlen célja jellemzően az extra profit szerzése, de a tényleges távolabbi cél annak legalizálása, majd a gazdasági és/vagy politikai hatalom megszerzése. A haszon azonnali felélése, a luxus életszínvonal kialakítása, a pazar, hivalkodó külsőségek ugyan megjelennek egyes csoportoknál, de a valóban veszélyes csoportok és azok vezetői már tudatosan tervezik jövőjüket, szívességekkel, befolyásokkal és befektetésekkel biztosítják későbbi pozíciójukat, hatalmukat.

\section{A szervezett bünözés hazai kialakulását és megerősödését elősegítő tényezők}

A szocialista rendszer kommunikációja nem viselte el, hogy a kapitalista társadalmakat terhelő szervezett bünözés hazai megjelenéséről tájékoztatást adjon, vagy egyáltalán beismerje létezését. Annak ellenére azonban, hogy titkolták és tiltakoztak ellene, a folyamat itthon is elindult és a bünözők egy része már tudatosan előkészítve, a szerepeket megosztva és a későbbi időszakra is felkészülve követte el cselekményeit. Mind ehhez kedvező feltételeket jelentett, hogy Magyarország az 1970-es években nyitottabbá vált, a turizmus fejlődött, egyre több külföldi érkezett hazánkba. Az ideérkezők egyrészt új elkövetési módszereket hoztak, másrészt fizetőképes keresletet jelentettek mind a vendéglátásban, mind pedig a prostitúció és az illegális mükincs-kereskedelem területén. Az 1980-as évek elején a gazdaság élénkülése, a $\mathrm{GMK}^{7}$ és a magánszektor kialakulása, a butikosok és vendéglősök világa egy új, tehetős réteget eredményezett, akik a vagyonukkal előszeretettel hivalkodtak. Ráadásul ennek egy nagyobb részét készpénzben vagy egyéb értéktárgyakban (nemesfém, mükincs, müszaki cikkek), minimális vagyonvédelmi berendezés nélkül tárolták otthonukban, így ideális célponttá váltak. A bünözés 1990-től kezdett robbanásszerüen emelkedni, az 1980-as években tapasztalt évenkénti 100-150 ezer büncselekmény 1991-ben már 440 ezerre nőtt, majd átmeneti csökkenés után 1998-ban 600 ezer cselekménynél tetőzött, aztán 400-450 ezres számnál stagnált évekig. Érdekes eredményt hoz a büncselekmény számainak emelkedése mellett az ismertté vált elkövetők számának összehasonlítása is. Míg a büncselekmények

6 Serious and Organised Crime Threat Assessment - a súlyos és szervezett bünözés fenyegetés-értékelése, melyet az Europol készít évente a tagállamok adatszolgáltatása alapján.

7 Gazdasági munkaközösség, 1982-2000. között létező polgári jogi társasági forma, mely a rendszerváltás előtti időszak jövedelem-kiegészítésének egyik államilag is elfogadott módozata volt. 
száma a vizsgált időszakban (1983-tól 1998-ig) 15 év alatt a négyszeresére nőtt (151 ezerről 600 ezerre), addig az elkövetők száma csak 68\%-kal emelkedett (83 ezerről 140 ezerre) (URL3).

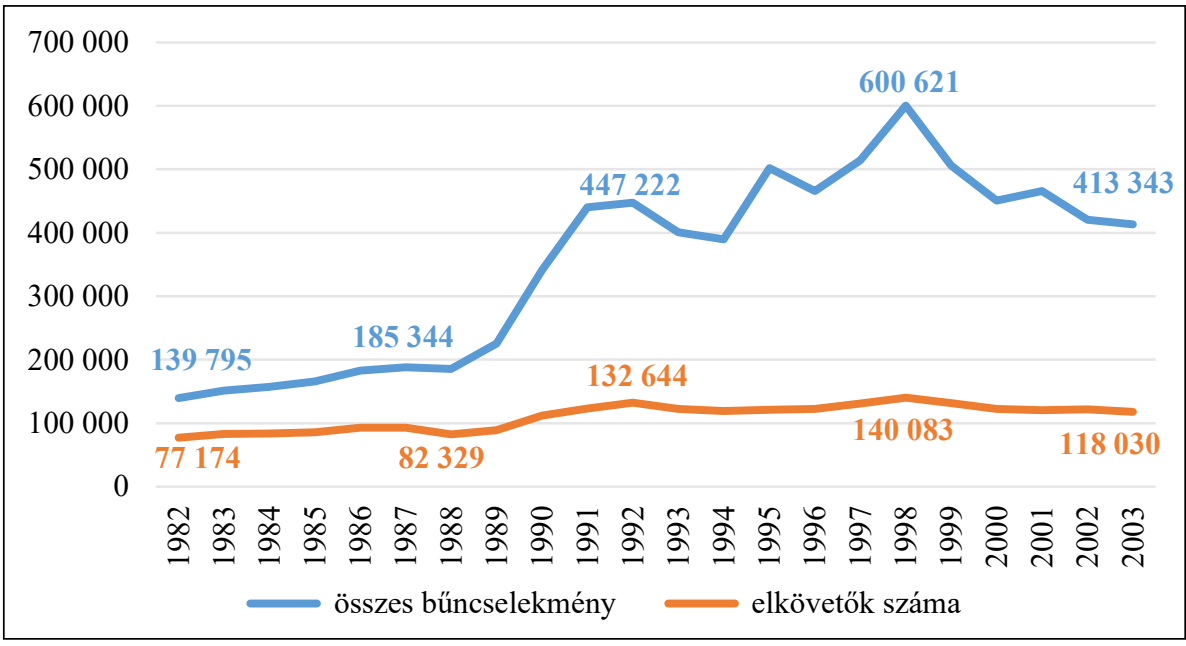

1. számú ábra: A büncselekmények és az ismertté vált elkövetők számának alakulása 1982-2003. között

Forrás: KSH Igazságszolgáltatási adatok 1965-től (URL3)

A rendszerváltást követően a jogszabályi hiányosságokat felismerő és kihasználó csoportok extrabevételekre tettek szert. Ezek közül ki kell emelni a fütőolaj és gázolaj adóterhe közötti eltérést kihasználó olajosokat. Ebben az időben a korábban betörések és más vagyon elleni büncselekmények miatt már a rendőrség látókörébe került és részben büntetett elöéletủ személyek egy csoportja megalakította az Energol Rt.-t, amely vezető szerepet töltött be a visszaélésekben. A vagyon és hatalom megszerzéséért, megtartásáért gyakorivá váltak a csoportok közötti összetüzések, melyek sok esetben utcai leszámoláshoz, lövöldözésekhez, robbantásokhoz vezettek az 1990-es években. Az időközben a környezö országokban végbement politikai változások és események, különösen a balkáni háború és a volt Szovjetunió szétesése - a hazai rendvédelmi szerveknél tapasztalt elbizonytalanodással párhuzamosan - egy korábban nem ismert eröszakos, fegyveres elkövetői réteget is kitermeltek. A háborút megjárt katonák nem riadtak el a lőfegyver vagy robbanóanyag használatától, és az elrettentés érdekében egyre drasztikusabban hajtották végre cselekményeiket. A szervezett bünözésnek, pontosabban annak még nemzetközibbé válásának új fejezete nyílt meg hazánk uniós tagságával 2001-ben, és a pár évvel később a schengeni-övezethez történt csatlakozásunkkal. Az ellenőrzött határok megszünése, 
az illegális migráció fokozódása, a virtuális informatikai világ újabb és újabb jelenségeket és működési területeket eredményeztek. Megszüntek az országok és tagállamok közötti távolságok és akadályok, az interneten a kommunikáció és a pénzügyi tranzakciók gyorsabbá, egyben nehezebben nyomozhatóvá váltak.

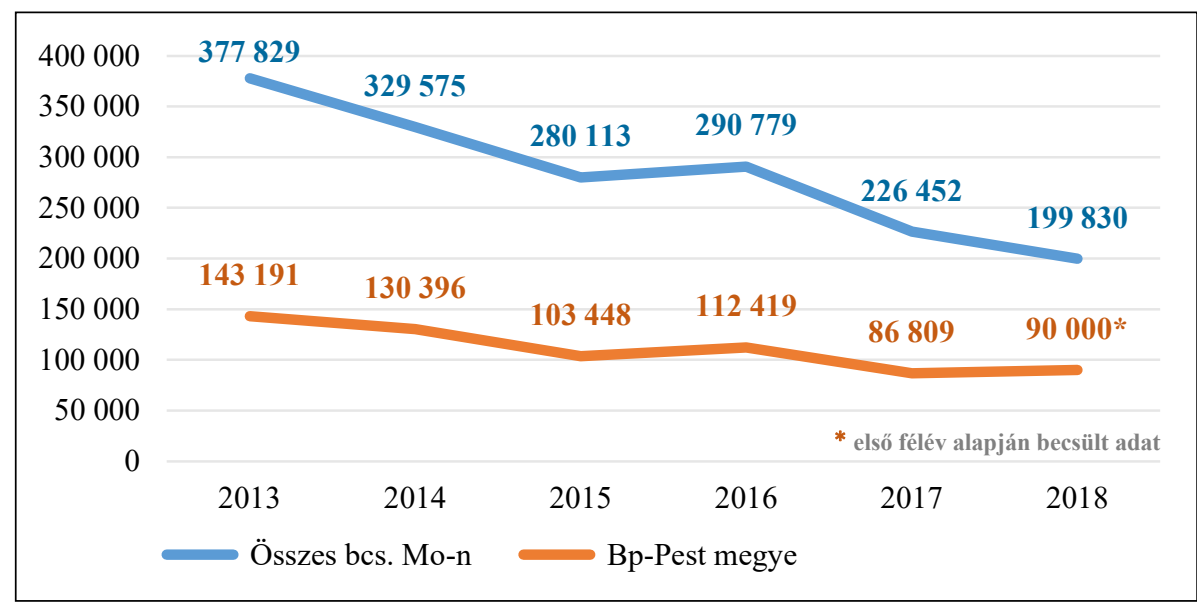

2. számú ábra: A bủncselekmények számának alakulása országosan, valamint Budapesten és Pest megyében, 2013-2018. között Forrás: ENYÜBS adatok (URL4)

A 2013-2018. közötti időszakban - mint ahogy az korábban is jellemző volt - a hazánkban elkövetett büncselekmények 35-45\%-át a fövárosban és annak közvetlen környezetében, Pest megyében követték el. Ez az arány magában foglalja a szervezett bünözéshez tartozó cselekményeket is, így ehhez igazodva a rendvédelmi szervek szervezeti egységei is ide koncentrálódtak.

A hazai szervezett bünözés fejlődése, átalakulása álláspontom szerint három nagyobb szakaszra bontható.

I. fázis: Az 1990-es évek elejéig tartó kezdeti, klasszikus szakasz. Erre az időszakra a prostitúció, kábítószer- és fegyverkereskedelem, illegális mükincs-kereskedelem, zsarolások, emberrablások, pénzhamisítás, a betöréses- és gépjármü lopások, a rablások voltak a jellemzők.

II. fázis: A 2000-es évek középéig tartó időszakban a korábban jellemző büncselekmények csökkenő intenzitása mellett megjelentek a gazdasági büncselekmények, az úgynevezett fehér galléros bünözés. A vagyonvédelmi cégek megjelenése, a hatékonyabb értékőrzés, a készpénz-forgalom csökkenése az erőszakos készpénzszerzés helyett újszerủ módszereket generált, így egyre nagyobb számban és kárértékben fordultak elő az adócsalások 
(beleértve a korszakot szimbolizáló olajos ügyek), gazdasági visszaélések, csalás sorozatok, amelyek hatalmas vagyonokat eredményeztek.

III. fázis: Napjainkban a virtuális tér, az internet által kínált lehetőségek, a terrorizmus terjedése és a kedvezötlen környezeti hatások miatt elindult migránsáradat újabb területeket biztosítanak a szervezett bünözésnek. Felértékelődött az információ és a személyes adat, amelynek megszerzése újabb távlatokat nyit meg a bünözés előtt, míg azok védelme a rendvédelmet állítja kihívások elé.

Természetesen nem lehet éles vonalat húzni az egyes fázisok között, egy folyamatosan változó, átalakuló világban a bünözés is állandóan változik. Mint ahogyan az egyes büncselekménytípusok is hol elszaporodnak, hol visszaszorulnak, elsősorban a társadalmi környezet, a várható profit vagy éppen a rendvédelmi szervek hatékonyságának függvényében.

\section{A szervezett bünözéssel foglalkozó egyes szervezetek, és azok jelentősebb változásai}

\section{Presztízs-ügy}

Minden, a hazai szervezett bünözéssel foglalkozó tanulmány a hatékony fellépés első lépcsőfokaként említi a Presztízs-ügyet. Az 1980-as évekre a kedvező társadalmi változások kitermeltek egy vagyonos vállalkozói réteget, akik a kor bűnözőinek potenciális sértetti kört jelentettek. A hirtelen jött jólét az éjszaki élet élvezetét, külföldi utazásokat, luxuslakásokat és autókat jelentettek, amelyeket egy erre érzékeny tippadói kör eredményesen érzékelt. Az arra hajlamos fodrászok, taxisok, felszolgálók jól jövedelmező részesedésért nevezték meg az újgazdagokat, és adták át a címeket. A tippek alapján a tucatnyi, egymást jól ismerő betörő - hol állandósult, hol ideiglenes csoportosulásban - előkészítette és végrehajtotta a betöréseket, majd elöre egyeztetett, ismert csatornákon értékesítették a zsákmányt. A végrehajtásban laza szerkezetü, de zárt elkövetői kör vett részt, amelynek tagjai szükség esetén egymást támogatták, kisegítették, és alibit biztosítottak. IBUSZ lakásokat béreltek, a megszerzett értékeket rejtekhelyeken tárolták, és volt köztük olyan betörö is, aki többszörös milliomosként tovább végezte takarítói munkáját, gondosan ügyelve arra, hogy az így szerzett ismereteket nem használta betörésekhez, nehogy gyanúba keveredjen (Pintér, 1983, 100.). Felkészültek egy lebukásra vagy tettenérésre, és azt követő eljárásra, ezért a készenlétben tartott ügyvédek szinte azonnal megjelentek. 
A rendörség szélmalomharcot vívott, a Budapesti Rendőr-fökapitányságon (BRFK) és a Pest Megyei Rendőr-főkapitányságon (PMRFK) elkülönítetten folytatott eljárások érdemi áttörést nem hoztak. Hiányzott az ügyek összehangolt elemzése, értékelése, és a nyomozások irányítása sem volt egységes. Ez változott meg 1982. január 11-től, miután a Belügyminisztérium Országos Rendőr-főkapitányság (BM ORFK) Bünügyi Csoportfőnökségén az ügyek összevonásra kerültek, és közös nyomozócsoportot állítottak fel. Az 1982. november 1-jéig müködö csoport munkája végül 85 terhelttel szemben 170 büncselekmény (ebből 143 betörés) elkövetésének a gyanúját alapozta meg, ami 21 millió forint kárértéket jelentett (Pintér, 1983, 96.). A nyomozócsoport olyan szakembereket tudhatott soraiban, mint Tonhauser László, aki médiaszereplései nyomán a bünügyi munka egyik legismertebb alakjává vált, Horváth András, a PMRFK későbbi bünügyi helyettese vagy dr. Pintér Sándor, Magyarország belügyminisztere. A korszakra jellemzően a csoport munkájának értékelésében hivatalosan nem szerepelt a szervezett elkövetés, helyette a sokvádlottas jelzőt használták. Szilbereky Jenő, a Legfelsőbb Bíróság akkori elnöke az 1983. február 7-én, az MSZMP Koordinációs Bizottságnak adott tájékoztatójának is $A$ sokvádlottas, kiemelkedö jelentöségü büntetö ügyekben az idöszerüség megvalósitásának akadályaival kapcsolatos tapasztalatokról címet adta (Tonhauser, 1999, 48-52.).

\section{Cattani-csoport}

A szervezett bünözés elleni fellépés következő mérföldköve a BRFK szervezetén belül 1990 szeptemberében életre hívott Cattani-csoport volt, ami a nevét a televízióban akkoriban vetített, és az olasz maffia elleni küzdelmet bemutató Polip címü filmsorozat főszereplöjéről kapta. A 15 fös egységet a kor legmodernebb technikai eszközeivel szerelték fel (például személyhívók, kocka Ladák, védőfelszerelések), és országos hatáskört kaptak. Feladatuk elsősorban a szervezett bünözésre akkoriban jellemző ügyek (zsarolás, prostitúció, pénzhamisítás) felderítése volt. A csoport tagjai a bünügyi szakterületről kerültek kiválogatásra, akik otthonosan mozogtak az erőszakos bünözés területén. Mind a csoport müködésében, mind pedig az érthetetlenül gyors megszüntetésében ellentmondások voltak. A fennállásuk alig több, mint egy éves időtartama alatt egyes tagok szerint 100, míg mások szerint 200 ügyet oldottak meg. Az ügyek között jellemzően ukrán emberrablások, védelmi pénzes zsarolások és pénzhamisítások szerepeltek. A legnevezetesebb ügyként az esztergomi Prímás-szigeten elkövetett zsarolás vált ismertté, ahol egy vendéglátóhelyet fenyegettek meg, és 10 ezer márkát követeltek védelmi pénzként. Ennek átvételére 1991. januárban az 
akkori egyik legismertebb alvilági személy, Sz. Lajos vezette felfegyverkezett csapat érkezett meg tíz autóval. Megpróbáltak ugyan nagyon óvatosak lenni, de ez nem sikerült nekik és mindannyian elfogásra kerültek. De hiába volt profi az akció végrehajtása, a bíróság végül mindenkit felmentett a vádpontok alól. Ez a felmentő ítélet magán viselte azon jegyeket, amelyek a felderítő tevékenységet ebben az időben erőteljesen jellemezték. Mind az eljáró nyomozók, mind a vezetőik elsősorban az intézkedés eredményességét tartották szem előtt, nem a bizonyítékok beszerzésének törvényességét vagy a későbbi bizonyíthatóságot. Mentségükre, ebben az időben még váratott magára a különleges eszközök, a fedett nyomozók alkalmazásának, vagy akár a titkos felderítés során beszerzett adatok büntetőeljárásban történő felhasználásának törvényi szabályozása. A másik ellentmondás az állítólagos politikai megbízások voltak. A csoport négy tagja évekkel a megszünés után egy közjegyző által hitelesített nyilatkozatban azt állította, hogy utasítást kaptak Torgyán József és az általa vezetett Független Kisgazda Párt állítólagos lejáratására, megfigyelésére. Az állítás kivizsgálására az akkori legföbb ügyész, dr. Györgyi Kálmán vizsgálatot indított, a nyilatkozatot tevő rendőröket a Parlament munkacsoportja meg is hallgatta, de az ügy érdemi megállapításait homály fedi a mai napig (URL5). Tény azonban, hogy 1991 decemberében a csoportot megszüntették, holott a szakmai hatékonyságuk és az általuk elért eredmények alapján müködésüknek lett volna létjogosultsága.

\section{Folytatás a Budapesti Rendőr-főkapitányságon}

A Cattani-csoport megszünésével nem tett le a szervezett bünözés elleni fellépésről a csoportot létrehozó Bodrácska János, aki időközben Budapest rendőrfőkapitánya lett. 1993. június 16-tól egy új, immár állandósult szervezeti egységként állította fel a BRFK-n a Szervezett Bünözés Elleni Osztályt. Az osztály hatásköre sokban hasonlított a Cattani-csoportéhoz, de illetékességi területe kizárólag a fővárosra korlátozódott. Újdonságként jelent meg az addig a gazdaságvédelemhez tartozó kábítószer-bünözéssel foglalkozó alegység beintegrálása, illetve egy önálló koordinációs szakterület felállítása.

Az osztály nyílt nyomozati jogkör nélkül végzett felderítő tevékenységet és hajtott végre elfogásokat. A felderítés eredményeként elfogott, intézkedés alá vont személyek ellen a büntetőeljárást a BRFK Vizsgálati Főosztályán kijelölt egység folytatta le. Ez a megosztottság azért továbbra is rányomta a bélyegét a szakmai munkára. Míg a felderítők termelték az ügyeket a vizsgálók számára, utóbbiak rendszeresen megkérdőjelezték azok megalapozottságát, törvényességét. De fordítva is voltak panaszok, a felderítők álláspontja szerint a vizsgálók 
túl körülményesek és lassúak voltak. Hogy hol volt az igazság? Valahol a kettő között, amit egy közös szakmai irányítás tudott volna megoldani. Az osztály müködését azonban később több visszaélés és botrány is beárnyékolta. Kiderült, hogy az egység egyik tagja betörésekből származó müszaki cikkeket árult, de folyamatosan keletkeztek információk az alvilággal történt összefonódásról is. A végső pontot egy 1998 elején a Margit hídon történt éjszakai baleset jelentette, amelyben a budapesti alvilági élet prominens személye mellett az egység tagjai sérültek, miután az átszórakozott este után egy autóban utaztak. Ezek az események elkerülhetetlenné tették a szervezet teljes megújítását, így 1998. március 1-jétől egy új felállásban, föosztályként müködött tovább. Jelentős személyi változások után a felderítés-nyomozás-vizsgálat egy szervezeten belül, egységes irányítás alatt, de külön osztályokon zajlott. Így házon belül egy vezető tudott dönteni a szakmai kérdésekben. A nyílt nyomozati jogkör egyben azt jelentette, hogy egyes ügyekkel az érvényes hatásköri szabályok alapján kötelezően kellett foglalkoznia az egységnek, így ide tartozott minden, a fövárosban elkövetett robbantás is. Márpedig 1998. március 11-től - amikor a Király utcai Halló bár elött robbant kézigránát - sorozatban történtek ilyen cselekmények Budapesten. Rövid időszakon belül Mercedesek, night klubok, a politikai elit lakásai és autókerekedések váltak robbantások helyszínévé. Mégis a szervezet nyomozói szakterületét a későbbiekben az emberrablások, a kábítószeres büncselekmények és más, erőszakos ügyek terhelték le leginkább. Ez az állapot sem maradt azonban hosszútávon változatlan. 1999. február 1-jétől egy újabb átfogó átszervezés létrehozta a BRFK-n a felderítő, nyomozó és vizsgálati föosztályokat, és a szervezett bünözés elleni küzdelem az adott főosztályokon belüli osztályokon folytatódott. Ez lényegében ismételten előhozta a korábbi szakmai nézetkülönbségeket. Kisebb átszervezésekkel vagy prioritást élvező büncselekményekre adott szervezeti válaszokkal (például a kábítószer elleni egység önálló osztállyá szervezése vagy a gépjármúlopásokra szakosodott Gepárd-csoport integrálása) az osztály 2012 közepéig müködött, majd jogutód nélkül megszüntetésre került a Hajógyári-szigeten lévő szórakozóhelyekkel kapcsolatos rendőri visszaélések miatt.

\section{Szervezett- és Kábítószer-Bünözés Elleni Szolgálat, Szervezett Bünözés Elleni Szolgálat, Központi Bünüldözési Igazgatóság}

A Cattani-csoport megszünése után a BRFK mellett országos szinten is igény jelentkezett egy szakmai egység létrehozására, amelyre a nemzetközi együttmüködés feladata is várt. Az 1990-es évek elején az olajos büncselekmények hatására 
egyes bünözői körök hatalmas vagyonra tettek szert, és úgy gondolták senki és semmi nem korlátozhatja tevékenységüket. Más csoportok szerették volna ennek a vagyonnak egy részét, vagy legalábbis az ezt eredményező illegális tevékenység végzésének a jogát megszerezni. Míg ezek a hatalmi törekvések a kezdetekben kevésbé látványos összetüzésekben kerültek letörésre, addig az afgán háborúból hazatérő veteránok, a balkáni háborút megjárt harcosok és az általuk könnyen megszerezhető fegyverek, robbanóanyagok újfajta küzdelmet hoztak. Ezzel párhuzamosan megjelentek újfajta kábítószerek, a nyugati világ elérhetősége új forrásokat hozott, továbbá a pénzhamisítás is új lehetőséget kapott. A határon átnyúló bünelkövetés, a külföldi bünözők megjelenése és összefonódása a hazai kemény maggal szükségszerủvé tette egy erre reagálni képes szervezet felállítását. Így 1990-ben az ORFK-n belül megalakult a Nemzetközi, Szervezett- és Kábítószer-Bünözés Elleni Szolgálat (NKBESZ). Mivel a névválasztás nem tünt a legszerencsésebbnek, így 1993-ban Szervezett Bünözés Elleni Szolgálatra (SZBESZ) módosították, tényleges szervezeti átalakítás nélkül. A fehér galléros bünözés, az olajügyek, illetve a banki szférát érintő büncselekmények szervezett elkövetési jellegét felismerve 1996. szeptember 1-jén a SZBESZ és az ORFK Gazdaságvédelmi Főosztálya összevonásra került, és megalakult egy új, közel 300 fős, országos hatáskörü, szervezett bünözés elleni egység, a Központi Bünüldözési Igazgatóság (KBI). A korábbiakkal ellentétben ez már nemcsak felderítéssel, hanem a feltárt vagy a hatáskörébe utalt büncselekmények vizsgálatával is foglalkozott, azaz konkrét büntetőeljárásokat is folytatott. A másik fontos újdonság a szervezetbe integrált elemzö-értékelő egység volt, amely a beszerzett információk szintetizálását, összefésülését, értékelését végezte. A KBI vezetője Kiss Ernő r. ezredes lett, aki az ORFK bünügyi főigazgató-helyettesi székéből került át oda (URL6). A Cattani-csoportnál megemlített jogszabályi hiányosságok itt is érezhetők voltak. A fedett müveletek, a nemzetközi együttmüködés (például egy ellenőrzött szállítás) végrehajtására nem volt törvényi felhatalmazás. Ugyan a megalakulás előtti évben kihirdetett rendörségi törvény ennek alapjait már letette, de a részletes szabályozásra és végrehajtási utasításokra még várni kellett. Az elődszervezetekkel szemben a KBI, illetve a NSZKBESZ (SZBESZ) már elkezdte a külföldi, elsősorban a nyugati tapasztalatok begyüjtését. Ezek elsősorban képzések, tanfolyamok, gyakorlatok megismerésében merültek ki. A német, osztrák rendőrökkel kialakított együttmüködés sok kiemelt ügyben rövid távon is eredményt hozott (például a budapesti zsinagóga sérelmére 1993-ban elkövetett betörés felderítése), de a hosszú távú hasznosulás ennél is jelentősebb volt. A külföldi példákból tanulva a KBI-n belül megjelent az a háttértámogató műveleti egység, amely később Bűnügyi Ellátó Igazgatóságként (BEI) önállósult. Ennek keretében létrehozták a fedett müveletekért felelős, valamint a lep- 
lezett megfigyelések és elfogások végrehajtására alkalmas taktikai osztályokat, és később a tanúvédelmi egységek is ide kerültek. A szervezett bünözés elleni harc nélkülözhetetlen elemei voltak ezek, amelyek az eljárások kezdeti szakaszától a bírósági döntést követően is alkalmasak voltak a hatóságok támogatására. Ugyanakkor a KBI munkáját visszatérően megnehezítették a belső hatalmi küzdelmek, a szakmai és a politikai érdekek ütközése, a fövárosban jelen lévő három szervezett bünözés elleni egység (BRFK-PMRFK-ORFK) közötti presztízsharcok. Központi koordináció hiányában gyakran az egyik felderítő szerv hosszú és eszközigényes felderítést folytatott a másik szerv által már ellenőrzött információra, vagy éppen egy másik szerv által folytatott fedett mủvelet főszereplőjét fogták el, pont mielőtt a beígért több kiló kábítószerhez érkezett volna.

\section{Szervezett Bünözés Elleni Igazgatóság, Nemzeti Nyomozó Iroda, Készenléti Rendőrség Nemzeti Nyomozó Iroda}

1998-ban új szervezet jött létre a KBI bázisán, a Szervezett Bünözés Elleni Igazgatóság (SZBEI). Az új egység küldetése szerint támadóbb jelleggel, szélesebb nyomozati jogkörrel és hatáskörrel kezdte meg munkáját. Elődleges feladata nem kizárólag a bünözésre vonatkozó információk begyüjtése volt, hanem azok bíróság előtti felhasználásával az eredményes nyomozások lefolytatása és a vádképviselet támogatása. A megalakulását felgyorsította Fenyő János vállalkozó 1998. február 11-ei meggyilkolása, majd 1998. július 2-án Boros Tamás felrobbantása a belvárosban, amelyben négyen vesztették életüket. A nemzetközi együttmüködés idővel még hangsúlyosabbá vált, különösen miután 2001-ben az amerikai Szövetségi Nyomozó Iroda (FBI - Federal Bureau of Investigation) Budapestre delegált ügynökeivel kiegészülve 10 fös munkacsoport kezdte meg munkáját. A Task-Force egység alapfeladata az orosz nyelvü bűnözés felderítése volt, de a 2001. szeptember 11-én New Yorkban végrehajtott merényletet követően a terrorizmus elleni fellépés és információcsere is kiemelt szerepet kapott. Miközben az SZBEI a felderítések mellett egyre fajsúlyosabb ügyekben folytatta a nyomozásokat (például Postabank ügy, Fenyő gyilkosság, Seuso-kincsek ügye), 2002-ben megtörtént az Európában is példátlan fegyveres bankrablás Móron, ami 8 emberéletet követelt. Az ügy nyomozása hatalmas energiát kötött le, és rávilágított olyan fejlesztési igényekre, amelyek végül 2004-ben valósultak meg. Az addig az ORFK szervezeti egységébe tartozó SZBEI átszervezésével önálló területi szervként ekkor jött létre a Nemzeti Nyomozó Iroda, amely az addigi APEH Pénzügyi Nyomozó Igazgatóságát is magába olvasztotta. 
2008-ban újabb bővülés következett be. Az ORFK Bünügyi Ellátó Igazgatóság (BEI), valamint a határőrségtől az illegális migrációval foglalkozó szakegység integrálásával tovább nőtt az NNI létszáma, feladatrendszere és egyben a képessége is. A BEI révén saját maga tudta a felderítés minden mozzanatát végrehajtani, a megfigyelésektől kezdődően, a fedett műveleteken át, egészen az eljárásban esetlegesen szükségessé vált tanúvédelemig. A felderítések az információ keletkezésétől egészen a nyomozás befejezéséig, vádemelésig egy kézben volt, egységes szakmai irányítás alatt. Ebben az időszakban is olyan, országos érdeklődésre számot tartó kiemelt ügyeket kellett megoldania, mint például a roma személyek elleni emberölés-sorozat, vagy a Magyarok Nyilai terrorszervezet felderítése.

A napi gyakorlati munka mellett hangsúlyossá vált a képzés és a nemzetközi együttmüködés folyamatossága is. Mind a müveleti, mind a klasszikus felderítő és nyomozó területen széles kapcsolatrendszer alakult ki. A határon átnyúló bünözés egyes területein (például bankkártya-hamisítás, kábítószer-kereskedelem, pénzhamisítás, prostitúció és emberkereskedelem) jelentős eredményeket és elismertséget értek el. 2012-ben az egység újabb átszervezésen esett át. A már korábban említett, és a Hajógyári-szigethez kapcsolódó bűnszervezet által korrumpált rendőri vezetők elfogását követően nemcsak a BRFK-n, hanem az NNI-nél is jelentős változások történtek. A szervezettől első lépésként a tanúvédelmi egység került a Készenléti Rendőrséghez, majd pár hónappal később a korábbi Bünügyi Ellátó Igazgatóság egyégei kerültek vissza az ORFK Bűnügyi Főigazgatóságára, míg az NNI maradék része is a Készenléti Rendőrség alegysége lett. Időközben az átszervezés mellett fejlesztésekre is sor került, így például jelentős létszámbővítést kapott a kiberbünözés elleni terület, ami korunk egyik legnagyobb kihívását jelenti.

\section{Szervezett Bünözés Elleni Koordinációs Központ, Terrorelhárítási Információs és Bünügyi Elemző Központ}

A bünözés elleni fellépés egyik sarkalatos pontja a rendelkezésre álló információk minél hatékonyabb felhasználása. Az ezredfordulón már világossá vált, hogy a korábbi értékelő, elemző egységek elszigetelt munkája nem elégséges ahhoz, hogy minden információ eljusson ahhoz, aki érdemben tud vele foglalkozni. Ennek a hiányosságnak a megszüntetésére 2001. január 1-jén megalakult a Szervezett Bünözés Elleni Koordinációs Központ (SZBEKK), mint a BM háttérintézményeként müködő önálló központi hivatal. Tevékenységének jogalapját a 2000. évi CXXVI. tv. és a 305/2006. (XII. 23.) kormányrendelet jelentette. A központ alapfeladata a részére eljuttatott adatok, információk koordinálása, 
értékelése, elemzése, az esetleges párhuzamosságok feltárása és ügyelemzés volt. Az ehhez szükséges adatokat az együttműködésre kijelölt szervek a törvényben nevesített büncselekményi körben küldték meg. A központ 2016. július 15-ig létezett, ekkor az ötödik, és a BM irányítása alatt lévő polgári nemzetbiztonsági szolgálatként a SZBEKK bázisán megalakult a Terrorelhárítási Információs és Bünügyi Elemző Központ (TIBEK). Az ötpárti megegyezés alapján felállított szervezet sokban örökölte az elődjének feladatrendszerét, de azok mellett újakat is kapott, többek között a kormányzati tájékoztatás, az utasadat-információs rendszer üzemeltetését, valamint a nyílt forrású elemző-értékelö tevékenységet, azaz az OSINT ${ }^{8}$-ot. Változás állt be a müködést szabályozó törvény vonatkozásában is. Az új egység munkáját már a nemzetbiztonsági szolgátokról szóló törvény ${ }^{9}$ szabályozza, ami az együttmüködő szervek részére az általuk üzemeltetett adatbázishoz on-line összeköttetés biztosítását írja elő. A fentiek lehetőséget adnak arra, hogy minden releváns információ egy helyen összpontosuljon, és hasznosíthatóvá váljon, függetlenül az adatot beszerző szervezet értékelésétől.

\section{A rendőrségen kívüli feladatok}

Természetesen nemcsak a rendőrség feladata a szervezett bünözés elleni fellépés. Sok szervezet az igazságszolgáltatás, a bünüldözés, hazánk biztonságának megóvása mellett járult (és járul) hozzá az eredményes küzdelemhez. A BM Határőrség is -2008-as megszünéséig - részt vállalt ebből a küzdelemből. Az akkor hatályos normák ${ }^{\mathbf{1 0}}$ alapján kizárólagos hatásköre volt az embercsempészés és a hozzá kapcsolódó közokirat-hamisítás nyomozására, amelyek már abban az időben is jövedelmező büncselekménynek számítottak, ́́gy a szervezett bünözés érdeklődési körébe tartozott. A nyomozások mellett a határellenőrzési alapfeladatból eredő lehetőségekkel, nyilvántartásokkal is támogatta a többi szervezet munkáját. A 2011-ben alakult Nemzeti Védelmi Szolgálat (NVSZ), és jogelődje a BM Rendvédelmi Szervek Védelmi Szolgálata a hatáskörébe tartozó védetti állomány és a szervezett bünözés összefonódása, bünös kapcsolatuk vizsgálata mellett az állományt veszélyeztető jelenségek elhárítására is hivatott. A szervezett bünözés egyik jellemzője a hatalom megszerzése, érdekérvényesítés és információszerzés biztosítása, amelyhez a rendvédelmi állományból előszeretettel igyekeznek kapcsolatokat kiépíteni. Erre mutatott rá a NVSZ feljelentése alapján

8 Open Source Intelligence - nyílt forrású hírszerzés.

9 A nemzetbiztonsági szolgálatokról szóló 1995. évi CXXV. törvény.

10 A határőrizetről és a Határőrségről szóló 1997. évi XXXII. törvény 43. §, illetve a büntetőeljárásról szóló 1973. évi I. törvény. 16. §. 
a Hajógyári-szigeten lévő szórakozóhelyeket üzemeltető V. László és társai ellen indított eljárás is. Ebben több - a BRFK és az NNI állományában vezetö beosztásban lévő - rendőrtiszt is vádlott lett, ami jól bizonyította az alvilág rendvédelem irányába mutatott befolyásolási törekvését. A gazdasági büncselekmények felderítése, a fehérgalléros bünözés elleni harc mindig is speciális szakképzettséget igényelt. Ezt a jogalkotók is így gondolták, és a Be. egyes büncselekmények nyomozására - és ezzel a titkos felderítésére is - a rendőrségen kívüli szervezetet jelölt ki ${ }^{11}$. A Nemzeti Adó és Vámhivatal (elötte VPOP és APEH Bünügyi Igazgatóság) ebből eredően a továbbiakban a rá vonatkozó NAV törvény ${ }^{12}$ IV. fejezete alapján olyan ügyekben (például költségvetési csalás, vám- és jövedéki orgazdaság) kizárólagos határkörrel jár el, amelyek tipikusan a szervezett bünözés müködési körébe tartoznak. A Be. 30. §-a alapján ugyancsak speciális az ügyészség nyomozói hatásköre. Az ebben nevesített nyílt nyomozások mellett titkos felderítésre is jogosult, amelyre a felhatalmazást - a Be.-ben megfogalmazott rendelkezéseken túl - az ügyészségi törvény ${ }^{13} 18$. $\S$-a adja meg részére, ami lehetőséget ad a hatáskörébe utalt elkövetői kör (például hivatalos személyek) korrupciós cselekményeinek feltárása is. Sok esetben azonban az önálló nyomozati jogkörrel nem rendelkező NVSZ vagy TEK feljelentései alapján is az ügyészség folytatja le a büntetőeljárást. A szervezett bünözés elleni küzdelemben törvényben címzett feladatai vannak a nemzetbiztonsági szolgálatoknak. A müködésüket szabályozó törvény ${ }^{14}$ mind a polgári, mind a katonai szolgálatok alapfeladatai között nevesíti ezt a feladatot, hol szó szerinti megjelöléssel (Információs Hivatal, Katonai Nemzetbiztonsági Szolgálat, TIBEK), hol pedig a szervezett bünözésre jellemző büncselekmények nevesítésével (Alkotmányvédelmi Hivatalnál a fegyver és kábítószer-kereskedelemmel kapcsolatos feladatok). A Nemzetbiztonsági Szakszolgálat önálló információgyüjtésre nem jogosult, de háttértámogatással, a hatáskörébe tartozó szolgáltatások teljesítésével nagymértékben támogatja a többi szervezet munkáját.

\section{A képzés fejlődése}

A szervezeti válaszok mellett nélkülözhetetlen a rendvédelmi oktatás és képzés folyamatos fejlesztése, a nemzetközi tapasztalatok megismerése és alkalmazása is. A hazai rendészeti oktatás rendszerében a Rendőrtiszti Főiskola, majd

11 A büntetőeljárásról szóló 2017. évi XC. tv. 34. § (2) bekezdése.

12 2010. évi CXXII. törvény a Nemzeti Adó- és Vámhivatalról.

13 2011. évi CLXIII. törvény az ügyészségről.

14 1995. évi CXXV. törvény a nemzetbiztonsági szolgálatokról. 
a jogutód Nemzeti Közszolgálati Egyetem Rendészettudományi Kara mindig kiemelt figyelmet fordított a szakmai képzésre. Az alapképzésen oktatott tantárgyak is foglalkoznak a témával, de a szükséges akkreditációt követően elindult MA képzés részeként 544 órában a szervezett bünözés elleni specializáció is bevezetésre került. Mindezek után a Rendészettudományi Doktori Iskola is lehetőséget nyújt a témában további tanulmányok folytatására, kutatási területek felvételére. A Rendészettudományi Kar mellett az NKE Nemzetbiztonsági Intézete is foglalkozik a szervezett bünözés kérdésével, a Nemzetbiztonsági alapismertek tananyag XXI. század biztonsági fenyegetéseit bemutató részében. Az egyetem a 2018-ban elindította a „Szervezett bünözés elleni küzdelem elmélete és gyakorlata" címü két féléves képzését is, amely bíróknak, ügyészeknek és a nyomozóhatóságok tagjainak nyújt újabb lehetőséget a téma részletesebb megismerésére.

Egy BBA ${ }^{15}$ pályázat keretében az egyetemen zajlik a Nemzetközi szervezett bünözés nyomozásának kutatása információáramlási szempontból címü kutatási program is. A nemzetközi tapasztalatok átvételében és közvetítésében mindig élenjáró Nemzeti Oktatási Központ (NOK) égisze alatt 1992-ben kezdte meg müködését a hét európai ország nemzetközi rendészeti képzését biztosító Közép-európai Rendőrakadémia (MEPA - Mitteleuropäische Polizeiakademie), majd 1995-től az FBI támogatásával a Nemzetközi Rendészeti Akadémia (ILEA - International Law Enforcement Academy). Mindkettő kiemelt figyelmet fordít a szervezett bünözés elleni fellépésre, az ezzel kapcsolatos tapasztalatok átadására. A NOK a további nemzetközi együttmüködésből is aktívan kiveszi a részét, így 2005-től az Európai Unió Bünüldözési Képzési Ügynökségének (CEPOL - The European Union Agency for Law Enforcement Training), 2014-től pedig a Nemzetközi Pénzügyi Nyomozói Akadémia (ICOFI - International College of Financial Investigation) képzéseit is szervezi. A szakmai oktatások mellett meg kell említeni a nyelvtanfolyamokat is, amelyek a nemzetközi szervezett bünözés elleni fellépéshez szintén nélkülözhetetlen tudást segítenek elsajátítani. A NOK szakmai munkájával elérte azt is, hogy az Európai Rendőrakadémiák Szövetsége (AEPC - Association of European Police Colleges) tagjai között legyen (URL7). A hazai képzések mellett az elmúlt évek, évtizedek alatt számos olyan lehetőség nyílt meg az érdeklődő szakemberek előtt, amelyek során külföldi képzésben nemzetközi tapasztalatokat, elméleti és gyakorlati ismereteket tudtak megszerezni. Ebben kiemelkedő partnerek voltak a német és osztrák szövetségi bünügyi hivatalok (BKA - Bundeskriminal Amt), illetve az

15 BBA-5.2.2-2015-00001 projekt - Belső Biztonsági Alap keretében megvalósuló, EU által finanszírozott támogatási program a 2014-2020. közötti költségvetési ciklusban. 
FBI, amelyek rendszeresen biztosítanak képzési és továbbképzési lehetőséget, többek között Münsterben vagy Quanticoban.

\section{Összegzés}

A szervezett bünözés - mint ahogy a társadalom - folyamatosan változik, alakul. Néha erőteljesebb a változás, és esetenként látványosabb, erőszakosabb a megjelenése, néha pedig úgy tünik, visszaszorulóban van. Önámítás lenne azonban azt hinni, hogy egyszer majd megszünik, és többet nem kell számolnunk vele. A hatékony fellépés folyamatos reakciókat, állandó fejlődést és szervezeti korszerüsítést, átalakítást, azaz választ igényel. A szervezett bünözést elősegítő körülmények időben történő felismerése, vagy az azokra időben tett intézkedések hatékonyabbá tehetik a küzdelmet, és sok esetben megtakarítással járnak mind a humánerő, mind az anyagi-technikai források tekintetében. Az elmúlt 30-40 év tapasztalatai kellő információt nyújtanak a korábbi szükséges és elkerülhetetlen intézkedésekről, és ezek szükség esetén támogathatnak egy újabb, eredményesebb fellépést biztosító változtatást.

\section{Felhasznált irodalom}

Bezsenyi T. (2015): Szervezett bünözés Magyarországon a rendszerváltás tükrében. In Kötetlen - Az ELTE Angelusz Róbert Társadalomtudományi Szakkollégium tanulmánykötete, 97-123.

Janzsó D. (2011): A szervezett bünözés kialakulása és jelenlétének sajátosságai, különös tekintettel a rendszerváltás hatásaira. Jogi Fórum, 36. https://www.jogiforum.hu/files/publikaciok/ janzso_donat_a_szervezett_bunozes_kialakulasa_es_jelenletenek_sajatossagai\%5bjogi_forum $\% 5$ d.pdf

Kovács I. (2015): „Olajozás”, szervezett bünözés és prostitúció a 90-es években Magyarországon. Nemzetbiztonsági Szemle, 3(1), 114-145.

Pintér S. (1983): Egy bünszövetség felszámolása. Belügyi Szemle, 31(8), 97-103.

Szendrei F. (2010): A pénzmosás. PhD értekezés, Pécsi Tudományegyetem, Állam- és Jogtudományi Kar, Doktori Iskola, 309.

Tonhauser L. (1999): Nem kérek bocsánatot. Totem Kiadó, 334. 


\section{A cikkben található online hivatkozások}

URL1: 5. ENSZ Kongresszus a bünözés megelözéséröl és az elkövetökkel szembeni fellépésröl (Toronto, 1975.09.01-02.). https://www.unodc.org/documents/congress//Previous_Congresses/5th_ Congress_1975/013_ACONF.56.3_Changes_in_Forms_and_Dimensions_of_Criminality.pdf URL2: A TANÁCS 2008/841/IB KERETHATÁROZATA (2008. október 24.) a szervezett bünözés elleni küzdelemröl. https://eur-lex.europa.eu/legal-content/HU/TXT/HTML/?uri=CELEX:32008F0841\&from=HU

URL3: Igazságszolgáltatás (1965- ). http://www.ksh.hu/docs/hun/xstadat/xstadat_hosszu/h_ zjj001.html

URL4: ENYÜBS statisztikai adatok. https://bsr.bm.hu/Document

URL5: Súlyos titkokat örizhetnek a cattanisok. https://www.origo.hu/itthon/20070627-cattanicsoport-sok-az-ellentmondas.html

URL6: Interjú Kiss Ernövel. https://24.hu/fn/gazdasag/1996/09/11/k_zponti_b_n_ld/

URL7: Nemzeti Oktatási Központ. http:/www.nokitc.hu/19/

URL8: A KBI születése - Tények könyve. https://www.arcanum.hu/hu/online-kiadvanyok/TenyekKonyve-tenyek-konyve-1/1997-11FD1/magyar-allam-tarsadalom-politika-14A60/a-parlamenti-partok-1996-ban-14EB3/a-kbi-szuletese-14F27/

URL9: SOCTA jelentés. https://www.europol.europa.eu/socta/2017/ 